\title{
Two Narrative Tactics Against Discourse of Mainstream Ideology: Rejection and Representation/Deconstruction
}

\author{
QIU Shi-cun \\ Southwest University, Chongqing, China \\ Sichuan University of Arts and Science, Dazhou, China
}

\author{
JIANG Deng-ke \\ Southwest University, Chongqing, China
}

\begin{abstract}
To get out of grand discourse of mainstream ideology, skillful writers have to do their best to find out an effective narrative tactic. In Ballad of Eternal Sorrow, which is a typical text of turning inside, WANG An-yi takes a tactic of rejection, taking grand historical discourse of the mainstream ideology as the background of the novel so as to draw a panorama of the everyday life of common Shanghai women. Against American Orientalism, The Woman Warrior has taken a representation/deconstruction narrative tactic to transform the heroic tradition of Chinese women (Brave Orchid, Fa Mu Lan and Ts'ai Yen) into American literary canon to empower the women's liberation movement in America.
\end{abstract}

Keywords: Ballad of Eternal Sorrow, The Woman Warrior, narrative tactic, rejection, representation/deconstruction

\section{Introduction}

In contemporary Chinese literature, a writer's lyric ego often "appears as a symbol of the national country" and this kind of "romantic imagination of nation" goes through ever since the independence and emancipation of the People's Republic of China (YIN, 1998, p. 82). However, in essence, history is a unity of all kinds of discourses; a history of customs and everyday trivial matters is perhaps a truer history than grand history. Ever since the publication of The Temptation of Kailas and You Have no Choice Other Than This in 1985, contemporary Chinese literature comes to highlight subjectivity of literature which thinks highly of the writer's expression of his or her life experience as well as the reader's creative understanding. Indeed, turning inside of Chinese literature is "a significant change from being satisfied with displaying or imitating outer world to facing up to the life itself” (XIE, 1998, p. 275). As a typical text of turning inside, WANG An-yi's Ballad of Eternal Sorrow (2003) takes a tactic of rejection to draw a panorama of the everyday life of common Shanghai women. Different from WANG An-yi, Maxine Hong Kingston (1989) has taken a representation/deconstruction narrative tactic against American Orientalism, to transform the heroic tradition of Chinese women into American literary canon to empower the women's liberation movement in America.

QIU Shi-cun, Ph.D. candidate, Modern Chinese Poetry Research Institute, Southwest University; lecturer, School of Foreign Language, Sichuan University of Arts and Science.

JIANG Deng-ke, professor, Ph.D., Modern Chinese Poetry Research Institute, Southwest University. 


\section{Turning Inside: A Tactic of Rejection}

In WANG An-yi's (2011) eyes, it is orthodoxy culture of the literati and officialdom and the ideal of "the whole world as one community" that get to make Chinese literature more and more "stereotyped and collectivization” (p. 139). To get out of this discourse of ideology, WANG An-yi took a tactics of rejection, taking grand historical discourse of the mainstream ideology as the background of the novel so as to draw a panorama of the everyday life of common Shanghai women, WANG Qi-yao as the focus. In this way, Ballad of Eternal Sorrow focuses on WANG Qi-yao's ordinary, intricate but self-respecting life story from the 1940s to the 1980s, displaying the true aesthetic form of life itself; the writer "takes a position of humanity to give her distinct attention to ups and downs of common Shanghai women and successfully makes a typical feminine text with feminine feeling and insight” (XU, MAO, \& DENG, 2005, p. 104).

To WANG An-yi, Shanghai women are the symbol of the city and Shanghai men are served as foils. In Ballad of Eternal Sorrow, there are three kinds of Shanghai men. One kind is those who court WANG Qi-yao, such as Mr. CHEN, KANG Ming-xun, Old Cooler, and Sasha. Most of them are shirkers who like to seek comfort from women. They first move WANG Qi-yao with their kindness, lovesickness, and thoughtfulness and then destroy bit by bit her passion to believe in and pursue love and hence comes WANG Qi-yao's tragedy at last. The second kind is those who have no names, such as WANG Qi-yao's father, JIANG Li-li's father and Mrs. YAN's husband. To Shanghai women, they are just "shadows" who they do definitely not want to place their ideal love and hope on. At last, Director LI seems to be the most mysterious and dignified Shanghai man who possesses both money and power. However, he is also just a symbol; once the political situation is changing, he "often dreams nightmare and struggles to cry out" (A. Y. WANG, 2003, p. 128) and needs to find comfort in WANG Qi-yao's tenderness. In contrast to Director LI who is at last destroyed by his political life, WANG Qi-yao's ongoing life desire symbolizes its value, which is "a kind of doubt and subversion to men's political life" and so let those passive WANG Qi-yaos "subvert traditional men-centered value” with their "subjective value” (JIANG, 2011, p. 187). Rejecting grand discourse of mainstream ideology, Ballad of Eternal Sorrow seems to show that Shanghai women intend to base their independence and pursuing on their perfection of feeling and love. However, they are doomed to failure, because those feminine or symbolic Shanghai men cannot help them to realize their dreams and well-being. WANG Qi-yao stands fast to her beliefs in despair; her tragic death is a seed of hope buried in despair, just like "pigeons going to take off... darting from their pigeonholes up to the sky” (A. Y. WANG, 2003, p. 430).

\section{The Woman Warrior: A Representation/Deconstruction Narrative Tactic}

In The Woman Warrior:Memoirs of a Girlhood Among Ghosts (1989), Maxine Hong Kingston's purpose is to “take people's preconceptions and break them apart” (Hoy, 1998, p. 54). Facing up to the extreme burden of American Orientalism, Kingston has taken a representation/deconstruction narrative tactic, representing American Orientalist stereotypes as well as implying and parodying some major characters in American literary canon, by which Kingston has both set up some instructive women characters for American literature and made a strong subversion of American Orientalism.

Before The Woman Warrior, the only presence of Chinese women in an anthology of American literature was the image of the "Oriental Wife” in the poem “The River-Merchant’s Wife: A Letter” (1915), a poem Ezra Pound 
translated from a Japanese version of a Chinese poem "Journey to Chang Gan" by LI Bai (618-907). Far from faithful to LI Bai's text, Pound has made a concrete image of the "Oriental Wife," who is forever chaste, domestic as well as wasting her youth alone in a garden. Pound's image of the "Oriental Wife" matches the desirable stereotypes in American Orientalism — the grieving Oriental woman, bashful, passive but sensual. When Kingston began to write The Woman Warrior, the image may have served as her point of departure to parody and deconstruct. For instance, "girl slavery" and "girl infanticide” are two notorious topics in Kingston’s criticism, as they are "sensational Orientalist tropes in media propaganda against China” (J. WANG, 2007, p. 123). Kingston (1989) is often quoted out of context of her reference to the word "slave": "There is a Chinese word for the Female I-which is 'slave'” (p. 47). In fact, the reference appears in the context when the narrator went to college at Berkeley and could not make sense of gender theory, so that the word is brought up as a paradox, an Orientalist Poundian cliché. It is an American Orientalist preconception to name Chinese women as "slaves”, which makes no sense of reality linguistically, historically, or culturally. In classical Chinese, a man uses the word to refer to himself as well. Moreover, it is an archaic usage, no longer used in modern Chinese language.

Indeed, it is instructive that the stories of Brave Orchid and Moon Orchid are read as deconstructive parodies that demystify the myth of the "River-Merchant's Wife”. Firstly, as Kingston had been reminded by her mother Brave Orchid that if she had been waiting for her husband to come back to China, the Hongs would never have a family in America or in China. In the "terrible ghost country", Brave Orchid raised six children, carrying "a hundred pounds of Texas rice up- and downstairs" and working at "the laundry from 6:30 a.m. until midnight" (Kingston, 1989, p. 104). Anyway, the mother is a strong woman and her love is possessive rather than self-sacrificing; her life experience precisely contradicts the quiet, bashful, and passive voice of the "River-Merchant's Wife".

Then, in contrast with Brave Orchid, her sister Moon Orchid is another kind of parody of the "Oriental Wife". She came to America, only to be completely rejected by her husband and lose her status as a wife, alienated in a culture in which she has no language to communicate with anyone including her sister and her children who are all Americans now. Accordingly, she goes crazy and ends her days at a mental asylum. Ironically, it is in this asylum that she finds her identity and "freedom of speech"; she becomes a mother to many young pregnant mad women and shares their language. Clearly, the language she speaks now is that she has newly acquired through her treatment in the American mental institution. Compared with the no-name aunt, Moon Orchid, a virtuous wife who has never committed adultery, should die among those pregnant mad women at a mental asylum, not in China but in America. Kingston seems to mean that Moon Orchid is not a Poundian "Oriental Wife” at all, but symbolizes a domestic American woman with hysterical character. Anyway, the mental asylum of dead souls becomes a metaphorical place for both Moon Orchid and her American "pregnant daughters", where their language is the language of death and their "freedom of speech" a lunatic hallucination.

In the early 1970s, to break the silence of women became not only a Chinese American theme, but also an all-American feminist theme. With the Women's Liberation Movement, sexual freedom and sexual liberation got prioritized in the feminist agenda. Consequently, in the then English curriculum, Hawthorne's The Scarlet Letter became a 1960s myth and Hester Prynne was “celebrated as the American New Eve” (J. WANG, 2007, p. 108). However, to Kingston who would not think much of her silence, Hester Prynne may represent a victim of Puritan patriarchal oppression more than a heroic model. In her imagination, Kingston could relate Hawthorne’s heroine 
to her no-name aunt, as she once mentioned in an interview: "When I was writing 'No Name Woman', I was thinking about Nathaniel Hawthorne and The Scarlet Letter as a discussion of the Puritan part of America" (Rabinowitz, 1998, p. 72).

As a postmodern parody of The Scarlet Letter, The Woman Warrior invents from a different transnational background Fa Mu Lan, Brave Orchid, and Ts'ai Yen, new American heroines who are not of silence like Hester Prynne. In fact, to the girl narrator, the source of silence does not derive from the story of her no-name aunt, but from that of Hester Prynne; neither in her mother's account nor in her imaginary speculation is there a trial scene of her aunt in the marketplace, or direct reference such as "I will not speak!" (Hawthorne, 1981, p. 64) as highlighted in The Scarlet Letter. The story of the no-name aunt is only a sensational prelude used to evoke the topic of women's liberation in America, not in China, for there is no presentation of the man's part, and even no mention of the "evil" man or stranger who made the no-name woman pregnant. It was just the daughter's curiosity to speculate who the man might be, and how he played his role: All is written in the subjunctive mood and "perhaps" appears in almost every paragraph. In contrast, it is Hester Prynne's persecution in the market-place, her evil lover and husband among the crowd, and her silence and self-effacing love that haunt Kingston's narrative consciousness like a nightmare. It is Hester Prynne's servitude of "I will not speak!" (Hawthorne, 1981, p. 64) that impregnates Kingston’s (1989) imagination of her no-name aunt: “To save her inseminator's name she gave silent birth" (p. 11).

It is true that silence or voice is a major concern in the narrator's search for identity. At school, for to be "American feminine" is to be sexy and soft-spoken and to live up to male fantasy, "all the time I was having to turn myself American feminine or no dates” (Kingston, 1989, p. 47); the Chinese girls are often recommended to have speech therapy, even though the therapists find their voice "unpredictably normal” (Kingston, 1989, p. 172). Gradually, Kingston gets to identify with her mother's voice; translated into English, the tone and voice of her mother's speech still contain the Chinese accent and aura marked by a polished and ornate complexity of the language. It is a language of necessity for survival in this new country, in which Kingston finds true freedom of self-expression and the power of resistance to oppression. By this language, Brave Orchid, unlike Hester Prynne, breaks the silence of American mothers and gives her daughter a family identity and impliedly warns against the consequence of adultery. By this language, Brave Orchid creates wonderful paradoxes which enable her narrator-daughter to stage contradictions and question the stereotypes of Chinese women in American Orientalist discourse. It raises a number of unnoticed but important questions: If the Chinese women were raised sexually promiscuous, why is sex a forbidden subject and sexual infamy punished in Chinese communities? If daughters were unwanted and baby-girls killed in Chinese societies, as often reported by the media, why should the grandfather trade a baby son for a baby daughter? Then, when he "finally got a daughter of his own", why did he "[dote] on her" (Kingston, 1989, p. 11)? Ironically, this daughter was the no-name aunt who committed adultery and suicide, harmed the family, and was forgotten by the family. To some extent, the no-name aunt is created as a question mark to challenge the stereotype of the forever chaste "Oriental wife".

Kingston's adaptation of Ts'ai Yen (a poet and historian) elaborates on her role of a wife and mother on an immigrant land, as a redressment of the same role of Hester Prynne. Ts'ai Yen is portrayed as a Chinese woman able to adopt the lifestyle and customs of the barbarians. Essentially, Kingston's ideal model role of a wife and mother is not a domestic wife of the kind of Hester Prynne, but a Woman Warrior together with men on the 
battlefields as a soul mate and a spokeswoman giving her conciliative feminine voice to silence soldiers. Kingston highlights Ts'ai Yen's role as a transnational women artist, whose role is to assimilate cultures and to preach as a peace-maker in wars or cultural conflictions. In a word, the story of Ts'ai Yen ultimately redresses the theme of unwanted daughters, family honor and family values provoked in the opening story "No Name Woman". Like the no-name woman, Ts'ai Yen was also a loved daughter who lost her body to "strangers". But she was reclaimed by her people, welcomed in court, ordered to be remarried, and carry on her family name "so that her father would have Han descendants” (Kingston, 1989, p. 209).

\section{Conclusion}

To sum up, to get out of grand discourse of mainstream ideology, a skillful writer will take an effective narrative tactic. In Ballad of Eternal Sorrow, WANG An-yi takes a tactics of rejection, taking grand historical discourse of the mainstream ideology as the background of the novel so as to draw a panorama of the everyday life of common Shanghai women. The fact that it has won the most important Chinese literature prize Mao Dun Literature Prize (2000) means that the mainstream discourse has accepted its validity. Against American Orientalism, The Woman Warrior has taken a representation/deconstruction narrative tactic to transform the heroic tradition of Chinese women (Brave Orchid, Fa Mu Lan and Ts'ai Yen) into American literary canon to empower the women's liberation movement in America.

\section{References}

Hawthorne, N. (1981). The Scarlet letter. New York: Bantam Doubleday Dell Publishing Group, Inc..

Hoy, J. (1998). To be able to see the Tao. In P. Skenazy \& T. Martin (Eds.), Conversations with Maxine Hong Kingston. Jackson: University Press of Mississippi.

JIANG, Z. Q. (2011). Acceptance and research of Chinese new period literature in foreign countries. Jinan: Qilu Press.

Kingston, M. H. (1989). The woman warrior: Memoirs of a girlhood among ghosts (Vintage International Edition). New York: Random House, Inc..

Rabinowitz, P. (1998). Eccentric memories: a conversation with Maxine Hong Kingston. In P. Skenazy \& T. Martin (Eds.), Conversations with Maxine Hong Kingston. Jackson: University Press of Mississippi.

WANG, A. Y. (2003). Ballad of eternal sorrow. Haikou: South Sea Publishing Company.

WANG, A. Y. (2011). Stories and telling stories. Shanghai: Fudan University Press.

WANG, J. (2007). The iron curtain of language: Maxine Hong Kingston and American Orientalism. Shanghai: Fudan University Press.

XIE, M. (1998). 1898: One hundred years' sufferings and concerns. Jinan: Shandong Education Press.

XU, Q. C., MAO, K. Q., \& DENG, J. W. (2005). Focusing on Mao Dun Literature Prize. Beijing: China Writers Publishing House. YIN, C. L. (1998). 1985: Extension and transition. Jinan: Shandong Education Press. 